\title{
Phytogenic silver, gold, and bimetallic nanoparticles as novel antitubercular agents
}

\author{
This article was published in the following Dove Press journal: \\ International Journal of Nanomedicine \\ 4 May 2016 \\ Number of times this article has been viewed
}

\author{
Richa Singh' \\ Laxman Nawale ${ }^{2}$ \\ Manisha Arkile ${ }^{2}$ \\ Sweety Wadhwani' \\ Utkarsha Shedbalkar' \\ Snehal Chopade' \\ Dhiman Sarkar ${ }^{2}$ \\ Balu Ananda Chopade ${ }^{1,3}$ \\ 'Department of Microbiology, \\ Savitribai Phule Pune University, \\ ${ }^{2}$ Combichem-Bioresource Center, \\ Organic Chemistry Division, \\ National Chemical Laboratory, Pune, \\ ${ }^{3}$ Dr Babasaheb Ambedkar Marathwada \\ University, Aurangabad, Maharashtra, \\ India
}

Purpose: Multi- and extensively drug-resistant tuberculosis (TB) is a global threat to human health. It requires immediate action to seek new antitubercular compounds and devise alternate strategies. Nanomaterials, in the present scenario, have opened new avenues in medicine, diagnosis, and therapeutics. In view of this, the current study aims to determine the efficacy of phytogenic metal nanoparticles to inhibit mycobacteria.

Methods: Silver (AgNPs), gold (AuNPs), and gold-silver bimetallic (Au-AgNPs) nanoparticles synthesized from medicinal plants, such as Barleria prionitis, Plumbago zeylanica, and Syzygium cumini, were tested against Mycobacterium tuberculosis and M. bovis BCG. In vitro and ex vivo macrophage infection model assays were designed to determine minimum inhibitory concentration (MIC) and half maximal inhibitory concentration of nanoparticles. Microscopic analyses were carried out to demonstrate intracellular uptake of nanoparticles in macrophages. Besides this, biocompatibility, specificity, and selectivity of nanoparticles were also established with respect to human cell lines.

Results: $\mathrm{Au}-\mathrm{AgNPs}$ exhibited highest antitubercular activity, with $\mathrm{MIC}$ of $<2.56 \mu \mathrm{g} / \mathrm{mL}$, followed by AgNPs. AuNPs did not show such activity at concentrations of up to $100 \mu \mathrm{g} / \mathrm{mL}$. In vitro and ex vivo macrophage infection model assays revealed the inhibition of both active and dormant stage mycobacteria on exposure to $\mathrm{Au}-\mathrm{AgNPs}$. These nanoparticles were capable of entering macrophage cells and exhibited up to $45 \%$ cytotoxicity at $30 \mu \mathrm{g} / \mathrm{mL}$ (ten times MIC concentration) after 48 hours. Among these, $\mathrm{Au}-\mathrm{AgNPs}$ synthesized from $S$. cumini were found to be more specific toward mycobacteria, with their selectivity index in the range of 94-108.

Conclusion: This is the first study to report the antimycobacterial activity of AuNPs, AgNPs, and $\mathrm{Au}-\mathrm{AgNPs}$ synthesized from medicinal plants. Among these, $\mathrm{Au}-\mathrm{AgNPs}$ from S. cumini showed profound efficiency, specificity, and selectivity to kill mycobacteria. These should be investigated further to develop novel TB nanoantibiotics.

Keywords: tuberculosis, mycobacteria, antimycobacterial agent, nanoparticles, drug resistance, cytotoxicity

\section{Introduction}

Tuberculosis (TB) affects millions of people every year and is ranked as the second leading cause of human death from an infectious disease after acquired immune deficiency syndrome. ${ }^{1}$ It is caused by Mycobacterium tuberculosis, which typically affects the lungs. Most people recover from primary TB infection without further evidence of the disease. However, the infection may stay dormant for years, and in some, it can reactivate. ${ }^{1}$ The probability of disease is higher in men, than in women, and immunocompromised adults. ${ }^{1}$ The treatment regimen includes combination of four first-line drugs, namely, rifampicin, isoniazid, pyrazinamide, and ethambutol. ${ }^{2}$ However, development of drug resistance among mycobacteria against these conventional antibiotics
Correspondence: Balu Ananda Chopade Dr Babasaheb Ambedkar Marathwada University, Jaisingpura, Aurangabad 431004, Maharashtra, India

Tel +9l 2402403 I I I

Fax +9l 24024031 I3

Email bachopade@gmail.com
International Journal of Nanomedicine 2016:I I 1889-1897

Dovepress

http://dx.doi.org/10.2147/IJN.S| 02488 (c) (1) \& () 2016 Singh et al. This work is published and licensed by Dove Medical Press Limited. The full terms of this license are available at https://www.dovepress.com/terms.php cc) and incorporate the Creative Commons Attribution - Non Commercial (unported, v3.0) License (http://creativecommons.org/licenses/by-nc/3.0/). By accessing the work you hereby accept the Terms. Non-commercial uses of the work are permitted without any further permission from Dove Medical Press Limited, provided the work is properly attributed. For permission for commercial use of this work, please see paragraphs 4.2 and 5 of our Terms (https://www.dovepress.com/terms.php). 
is a matter of great concern requiring immediate attention. Improper use of drugs, inappropriate treatment regimen, and failure to ensure its completeness in TB patients lead to the development of drug-resistant mycobacterial strains. ${ }^{3}$ There are reports on multidrug-resistant (MDR)- and extensively drug-resistant (XDR)-TB, which requires second-line anti-TB drugs, such as capreomycin, levofloxacin, terizidone, clarithromycin, and linezolid. ${ }^{4}$ Treatment of both MDRand XDR-TB is longer, costly, and has more side effects. ${ }^{3,4}$ According to the World Health Organization, 105 countries have reported XDR-TB cases. Globally, 3.7\% of new cases and $20 \%$ of the previously treated cases were estimated to have MDR-TB. The average proportion of MDR-TB cases with XDR-TB is $9.7 \%{ }^{3}$ Since MDR- and XDR-TB have become serious problems worldwide, there is an urgent need to discover new antitubercular compounds. Great efforts have been made to find both synthetic compounds and natural products to battle MDR- and XDR-TB. ${ }^{5-7}$ Nanotechnology offers a novel and promising approach to devise alternate antimycobacterial formulations.

In our earlier report, we demonstrated the antimycobacterial potency of silver nanoparticles (AgNPs) synthesized through bacterial and chemical reduction. ${ }^{8}$ Although those AgNPs exhibited mycobactericidal activity, their selectivity index was too low (up to 23) as compared to the standard anti-TB drug, rifampicin. Recently, bimetallic nanoparticles comprising of gold and silver have been reported to possess greater antimicrobial activity than monometallic ones..$^{9,10}$ Synthesis of such bimetallic nanoparticles employing bacteria is a rare phenomenon. However, phytosynthesis of bimetallic nanoparticles has received major attention because of clean, nontoxic, and eco-friendly procedures. ${ }^{11}$ Barleria prionitis, Plumbago zeylanica, and Syzygium cumini are well-known medicinal plants. The leaves, roots, and bark of these plants are used to cure stomach disorders, sore throat, toothache, bronchitis, asthma, thirst, urinary infections, biliousness, dysentery, fever, piles, feet laceration, ulcer, and pimples. ${ }^{12,13}$ Plumbagin, a major flavonoid present in roots of $P$. zeylanica, exhibits plasmid-curing and antimicrobial property. ${ }^{14,15}$ Phytochemical analysis of solvent extracts indicated the presence of glycosides, saponins, phenols, flavonoids, steroids, tannins, etc, which may lead to enhanced medicinal properties and biocompatibility in metal nanoparticles beneficial for therapeutic applications. ${ }^{9}$ Moreover, phytogenic metal nanoparticles are reported to possess antimicrobial property. ${ }^{9,10,16}$ Therefore, we extended the study to screen phytogenic AgNPs, gold nanoparticles (AuNPs), and gold-silver bimetallic nanoparticles (Au-AgNPs) for their antimycobacterial activity to develop novel and nonclassical antitubercular agents.

\section{Materials and methods Chemicals}

Dubos medium was purchased from Difco, Detroit, MI, USA. Luria-Bertani (LB) broth, Dulbecco's Modified Eagle's Medium (DMEM), Roswell Park Memorial Institute (RPMI) 1640 medium, fetal bovine serum (FBS), minimum essential medium (MEM), sodium pyruvate, sodium nitrate, and amino acids were procured from HiMedia, Mumbai, India. Ampicillin, gentamicin, rifampicin, dimethyl sulfoxide (DMSO), 4',6-diamidino-2-phenylindole (DAPI), phorbol myristate acetate, and MTT dye (3-[4,5-dimethylthiazol-2-yl]-2,5diphenyltetrazolium bromide) were obtained from SigmaAldrich (St Louis, MO, USA).

\section{Nanoparticles}

Three AgNPs (S1, S2, and S3), AuNPs (G1, G2, and G3), and bimetallic $\mathrm{Au}-\mathrm{AgNPs}$ (B1, B2, and B3) were used for preliminary screening against mycobacteria (Table 1). These nanoparticles were synthesized in our laboratory using B. prionitis leaf extract (S1, G1, and B1), P. zeylanica root extract (S2, G2, and B2), and S. cumini bark extract (S3, G3, and B3) using the protocol described elsewhere. ${ }^{9}$

\section{Mycobacterial cultures}

Standard cultures of $M$. bovis BCG (ATCC 35743) and M. tuberculosis H37Ra (ATCC 25177) were procured from American Type Culture Collection (ATCC), Manassas, VA, USA. M. bovis and M. tuberculosis were grown in Dubos medium supplemented with $50 \mathrm{mM}$ sodium nitrate and chemically defined $M$. phlei medium, ${ }^{17}$ respectively. The cultures were grown to $\log$ phase optical density $\left(\mathrm{OD}_{595}=1\right)$ under aerobic conditions at $37^{\circ} \mathrm{C} / 150 \mathrm{rpm}$. Since mycobacteria grow in aggregated clumps, these were sonicated for 2 minutes using water bath sonicator (Ultrasonic, Freeport, IL, USA)

Table I Morphology of phytogenic metal nanoparticles used for primary screening

\begin{tabular}{llll}
\hline Source & AgNPs & AuNPs & Au-AgNPs \\
\hline Barleria prionitis & $10-120 \mathrm{~nm}$ & $15-35 \mathrm{~nm}$ & $10-70 \mathrm{~nm}$ \\
& polydisperse & polydisperse & polydisperse \\
Plumbago zeylanica & $60 \mathrm{~nm}$ & $20-30 \mathrm{~nm}$ & $90 \mathrm{~nm}$ \\
& spherical & spherical, triangle & hexagonal \\
Syzygium cumini & $9-35 \mathrm{~nm}$ & $14-60 \mathrm{~nm}$ & $10-20 \mathrm{~nm}$ \\
& polydisperse & polydisperse & spherical \\
\hline
\end{tabular}

Abbreviations: AgNPs, silver nanoparticles; AuNPs, gold nanoparticles; Au-AgNPs, gold-silver bimetallic nanoparticles. 
to obtain dispersed cells. This step ensures the reproducibility of mycobacterial inoculation for experiments. For experiments, the active and dormant bacilli were cultivated in 96-well microtiter plates as per the protocol described by Khan and Sarkar. ${ }^{17}$

\section{Preliminary screening}

The phytogenic nanoparticles were screened for their inhibitory activity against dormant (12 days incubation) and active (8 days incubation) mycobacteria at concentrations of 0.1 , $0.3,1,3,10,30$, and $100 \mu \mathrm{g} / \mathrm{mL}$. Activity against $M$. bovis was estimated through nitrate reductase (NR) assay, reading absorbance at $540 \mathrm{~nm} .{ }^{17} \mathrm{XTT}$ reduction menadione assay (XRMA) was performed to determine the inhibition of M. tuberculosis. ${ }^{18}$ The absorbance of XRMA was measured at $470 \mathrm{~nm}$. Percentage inhibition was calculated using the following formula:

$$
\% \text { Inhibition }=\frac{\text { Control }-\mathrm{NP}}{\text { Control }- \text { Blank }} \times 100
$$

where control is the activity of mycobacteria without nanoparticles; NP is the activity of mycobacteria in the presence of nanoparticles; and blank is the activity of culture medium without mycobacteria.

The experiment was performed in triplicate, and the quantitative value was expressed as the mean \pm standard deviation.

\section{In vitro and ex vivo minimum inhibitory concentration and $\mathrm{IC}_{50}$}

Depending upon primary screening, dose-response assay was performed in vitro and ex vivo using AuNPs, AgNPs, and $\mathrm{Au}-\mathrm{AgNPs}$ at concentration range of $0.02-2.56 \mu \mathrm{g} / \mathrm{mL}$ to estimate their minimum inhibitory concentration (MIC) and half maximal inhibitory concentration $\left(\mathrm{IC}_{50}\right)$ against mycobacteria. In vitro activity against $M$. tuberculosis and M. bovis at active ( 8 days) and dormant (12 days) stage was performed using XRMA and NR assay, ${ }^{17,18}$ respectively, as described in the "Preliminary screening" section.

Ex vivo infection model assay was performed on human acute monocytic leukemia cell line (THP-1) after approval from the Institutional Ethical Committee, National Chemical Laboratory, Pune. The cell line was procured from the National Centre for Cell Science (NCCS), Pune, India, and the cells were cultured in RPMI 1640 medium supplemented with FBS $(10 \%)$, sodium pyruvate $(1 \mathrm{mM})$, nonessential amino acids (1\%), glutamine $(1 \%)$, gentamicin $(50 \mathrm{mg} / \mathrm{mL})$, and ampicillin
$(50 \mathrm{mg} / \mathrm{mL})$, and incubated at $37^{\circ} \mathrm{C}$ in an atmosphere of $5 \%$ $\mathrm{CO}_{2}$. For infection model study, $3 \times 10^{5} \mathrm{THP}-1$ cells $/ \mathrm{mL}$ were passaged in complete RPMI having phorbol myristate acetate $(100 \mathrm{nM} / \mathrm{mL})$ in 96-well microtiter plates and plated for differentiation to macrophages for 24 hours. These were further infected with $\log$ phase $M$. tuberculosis at 100 multiplicity of infection for 12 hours. Plates were thoroughly washed with phosphate-buffered saline (PBS, pH 7.2), followed by addition of fresh MEM medium containing $50 \mathrm{mM}$ sodium nitrate. Infected cells were then exposed to different concentrations of nanoparticles. Activity of nanoparticles was estimated through NR assay, ${ }^{17}$ as described in the "Preliminary screening" section, at the end of incubation period for active and dormant mycobacteria. Dose-response curve was plotted using OriginPro software (OriginLab Corporation, Northampton, MA, USA). The lowest concentration of nanoparticle exhibiting growth inhibition of $\geq 90 \%$ and $50 \%$ with respect to the growth control without nanoparticles were taken as the MIC and $\mathrm{IC}_{50}$, respectively. Rifampicin was used as a positive control. All experiments were carried out in triplicate.

\section{Nanoparticle internalization in macrophages}

THP-1 cells were grown in 96-well microtiter plates having glass bottom for 24 hours, followed by treatment with $30 \mu \mathrm{g} / \mathrm{mL}$ concentration of bimetallic nanoparticles for 24 and 48 hours. After treatment, cells were fixed using $4 \%$ paraformaldehyde (prepared in PBS) at $4^{\circ} \mathrm{C}$ for 2 hours. The plates were thoroughly washed with sterile PBS and stained with DAPI $(2 \mu \mathrm{g} / \mathrm{mL})$ to visualize the nucleus. The imaging was carried out under CX5 High Content Screening (HCS) Platform (Thermo Fisher Scientific, Waltham, MA, USA) using 386 and $650 \mathrm{~nm}$ excitation wavelength. The three-dimensional (3D) multichannel-image processing was done using Thermo Scientific HCS Studio 2.0 Cell Analysis Software.

\section{Cytotoxicity assay}

The effect of nanoparticles to inhibit cell proliferation was determined using human tumor cells, including acute monocytic leukemia cell line THP-1 (NCCS), and lung adenocarcinoma cell line (A549) and pancreas adenocarcinoma cell line (PANC-1) obtained from the European Collection of Cell Cultures, Salisbury, UK. THP-1 cells were maintained in RPMI 1640 medium, while A549 and PANC-1 cells were maintained in DMEM. These media were supplemented with $10 \% \mathrm{FBS}$ and $50 \mathrm{mg} / \mathrm{mL}$ gentamicin. The cell lines were maintained at $37^{\circ} \mathrm{C}$ and $5 \% \mathrm{CO}_{2}$ in a humidified environment. In vitro cytotoxicity against these human cell lines 
was determined using MTT assay as described previously. ${ }^{19}$ Briefly, log phase cells were harvested using trypsin $(0.05 \%$ trypsin, $0.02 \%$ ethylenediaminetetraacetic acid, in PBS) from tissue culture flask. The suspension was diluted with appropriate culture medium to obtain cell density of $10^{5}$ cells $/ \mathrm{mL}$ as determined by hemocytometry. An aliquot of $100 \mu \mathrm{L}$ of each suspension was seeded in 96-wells cell culture plates, and these were incubated at $37^{\circ} \mathrm{C}$ in a $\mathrm{CO}_{2}$ incubator (Thermo Fisher Scientific) for 24 hours. Cells were then treated with nanoparticles $(1 \mu \mathrm{L} /$ well $)$ at varying concentrations of 100 , 30,10 , and $3 \mu \mathrm{g} / \mathrm{mL}$ for 48 hours. After this, the wells were washed thoroughly with PBS to remove unattached cells. Furthermore, $10 \mu \mathrm{L}$ MTT ( $5 \mathrm{mg} / \mathrm{mL}$ in PBS) was added to the adhered cells in growth medium, and the plates were incubated at $37^{\circ} \mathrm{C}$ for 4 hours for MTT cleavage. The formazan product thus formed was solubilized by the addition of $100 \mu \mathrm{L} \mathrm{HCl}(0.04 \mathrm{~N})$ in isopropanol. Absorbance was measured on a SpectraMax ${ }^{\circledR}$ PLUS 384 plate reader (Molecular Devices LLC, Sunnyvale, CA, USA) at wavelength of $570 \mathrm{~nm}$. Percentage cytotoxicity was calculated using the following formula:

$$
\% \text { Cytotoxicity }=\frac{\text { Control }- \text { NP }}{\text { Control }- \text { Blank }} \times 100
$$

where control is the cell growth in medium without nanoparticles; NP is the cell growth in the presence of nanoparticles; and blank is the culture medium without cells.

The experiment was performed in triplicate and the quantitative value was expressed as the mean \pm standard deviation. Paclitaxel, an anticancer drug, was used as a positive control. Suitable controls with equivalent concentration of DMSO were also included.

\section{Specificity of Au-AgNPs}

Nanoparticles at concentrations of $0.1,0.3,1,3,10,30$, and $100 \mu \mathrm{g} / \mathrm{mL}$ were tested against Gram-negative and -positive bacterial pathogens to determine their specificity. Escherichia coli (NCIM 2931), Staphylococcus aureus (MTCC 3160), and Streptococcus mutans (MTCC 497) were obtained from National Collection of Industrial Microorganisms (NCIM), Pune, India, and Microbial Type Culture Collection (MTCC), Chandigarh, India. Acinetobacter baumannii AIIMS 7 (GenBank EU779829) isolated in our laboratory has been used in the study. The cultures were grown in LB medium at $37^{\circ} \mathrm{C} / 150 \mathrm{rpm}$. For antibacterial assay, OD-adjusted $\left(\mathrm{OD}_{620}=1\right)$ culture was inoculated in LB broth $(1 \% \mathrm{v} / \mathrm{v})$. In 96-well microtiter plate, $5 \mu \mathrm{L}$ nanoparticles, and $245 \mu \mathrm{L}$ culture were dispensed, and plates were incubated at $37^{\circ} \mathrm{C}$ for 18 hours, followed by reading the absorbance at $620 \mathrm{~nm}$. Ampicillin was taken as a positive control. Wells for growth and sterility control were also included. MIC and $\mathrm{IC}_{50}$ values were calculated from the dose-response curve.

\section{Selectivity index}

Selectivity index was calculated by dividing lethal concentration, $50 \%\left(\mathrm{LC}_{50}\right)$ for cell lines by the MIC for in vitro activity against active/dormant $M$. tuberculosis. ${ }^{20} \mathrm{LC}_{50}$ was taken as the lowest concentration of nanoparticles killing $50 \%$ of the cells as obtained from the percentage cytotoxicity curve plotted using OriginPro.

\section{Results and discussion \\ Preliminary screening}

In this study, mono-(AuNPs and AgNPs) and bimetallic (Au-AgNPs) nanoparticles synthesized from plants have been compared for their antitubercular activity. AgNPs are well known for their antimicrobial nature and have been shown to kill bacteria, fungi, and yeast alone and in combination with various antibiotics. ${ }^{16}$ AgNPs synthesized from leaf extract of Psidium guajava are demonstrated to have inhibitory effect on mycobacteria through disc diffusion assay. ${ }^{21}$ Naik et al ${ }^{22}$ reported the antimycobacterial activity of leaf extracts of Artemisia nilagirica and Murraya koenigii. Few studies have also described the mycobactericidal activity of chemical and microbial AgNPs. ${ }^{8,23,24}$ However, there are no reports on antitubercular effects of bimetallic $\mathrm{Au}-\mathrm{AgNPs}$. Moreover, this is the first study to compare the mycobactericidal efficacy of phytogenic AuNPs, AgNPs, and $\mathrm{Au}-\mathrm{AgNPs}$ synthesized using extract from three medicinal plants viz B. prionitis, P. zeylanica, and S. cumini (Table 1). In preliminary screening, all nine nanoparticles $(\mathrm{S} 1, \mathrm{~S} 2, \mathrm{~S} 3$, G1, G2, G3, B1, B2, and B3) were tested against active and dormant $M$. bovis BCG and M. tuberculosis at concentrations $0.1,0.3,1,3,10,30$, and $100 \mu \mathrm{g} / \mathrm{mL}$. Figure 1 shows the percentage inhibition obtained at $3 \mu \mathrm{g} / \mathrm{mL}$ concentration of nanoparticles. Bimetallic Au-AgNPs (B1, B2 and B3) exhibited profound mycobactericidal potency, inhibiting $>90 \%$ of mycobacterial growth at $3 \mu \mathrm{g} / \mathrm{mL}$. Phytogenic Au-AgNPs from P. zeylanica and Dioscorea bulbifera have been reported to possess antibacterial, antibiofilm, and antileishmanial activity. ${ }^{9,10}$ On exposure to AgNPs, 60\%-85\% inhibition was observed except $\mathrm{S} 2$, which showed up to $32 \%$ inhibition against dormant mycobacteria. This is in accordance with the earlier studies on antimicrobial property of AgNPs. ${ }^{25,26}$ Since dormancy is the reversible state of 


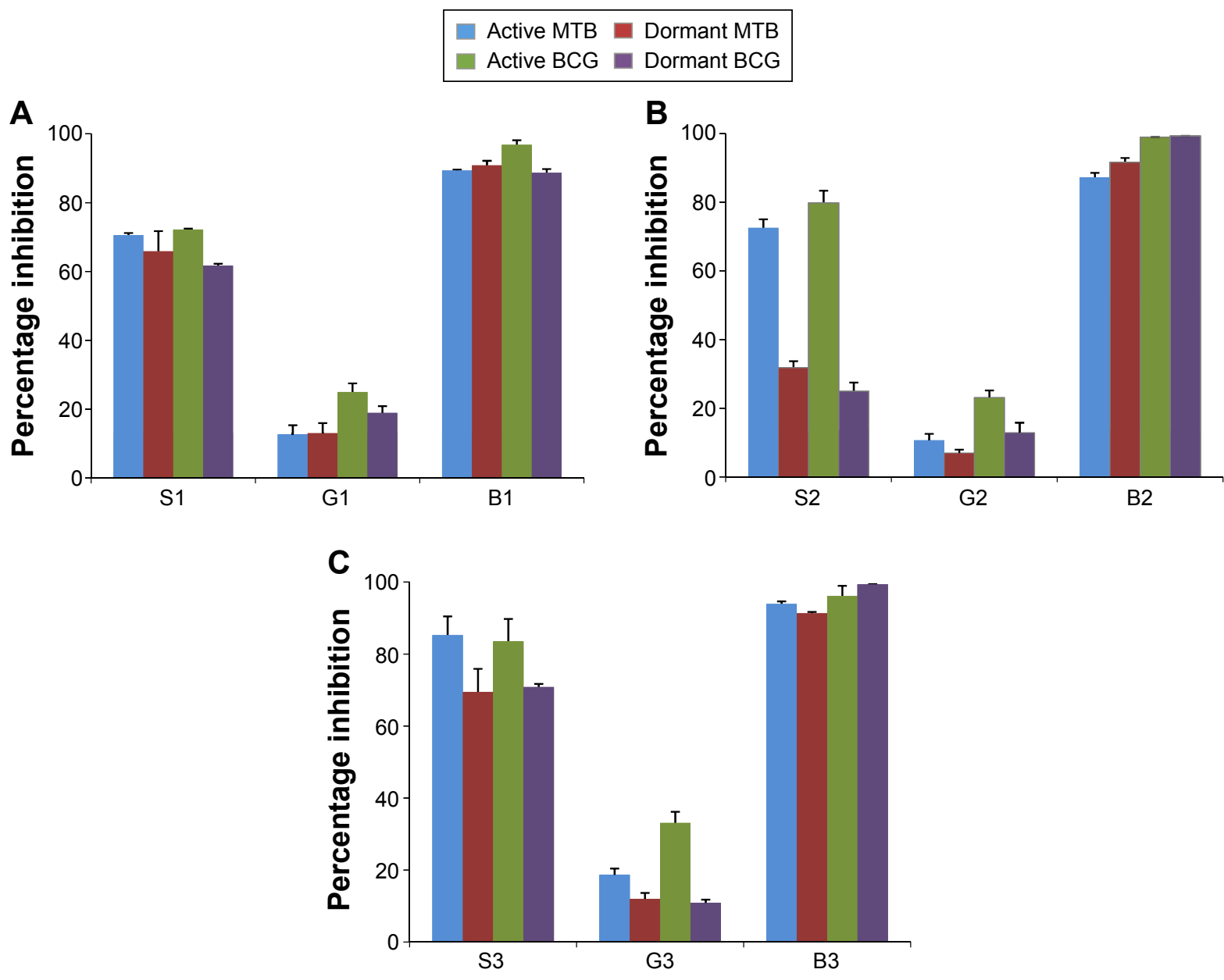

Figure I Percentage inhibition of active and dormant stage mycobacteria in the presence of $3 \mu \mathrm{g} / \mathrm{mL}$ silver, gold, and gold-silver bimetallic nanoparticles synthesized from (A) Barleria prionitis, (B) Plumbago zeylanica, and (C) Syzygium cumini.

Notes: SI, S2, and S3, silver nanoparticles; GI, G2, and G3, gold nanoparticles; BI, B2, and B3, gold-silver bimetallic nanoparticles. Abbreviations: MTB, Mycobacterium tuberculosis H37Ra (ATCC 25I77); BCG, M. bovis BCG (ATCC 35743).

metabolic shut down, mycobacteria offer greater resistance to treatment in dormant stage than active ones. Even at the highest concentration of $100 \mu \mathrm{g} / \mathrm{mL}$, AuNPs showed least activity in inhibiting mycobacteria contradicting the report on antimicrobial activity of AuNPs. ${ }^{27}$ Size- and shapedependent antimicrobial activity of metal nanoparticles has been reported, which could explain the difference in action of nanoparticles against mycobacteria. ${ }^{28,29}$ Owing to uniform shape and size, monodispersed nanoparticles are suggested to be more effective than polydispersed nanoparticles. ${ }^{30}$ Moreover, additive effect of silver and gold components in $\mathrm{Au}-\mathrm{AgNPs}$ may render them highly active against mycobacteria compared to AgNPs and AuNPs. ${ }^{9}$

\section{In vitro and ex vivo $\mathrm{MIC}$ and $\mathrm{IC}_{50}$}

These phytogenic nanoparticles were further tested to determine their $\mathrm{MIC}$ and $\mathrm{IC}_{50}$ against mycobacteria under in vitro and within THP-1 host macrophages (Table 2). In accordance with Figure 1, in vitro studies against M. bovis BCG and M. tuberculosis revealed the strongest antitubercular activity of Au-AgNPs (B1, B2, and B3). Among Au-AgNPs, B3 was found to be highly effective to inhibit both active and dormant mycobacteria, with MIC ranging from 0.32 to 1.05 $\mu \mathrm{g} / \mathrm{mL}$. MIC $(>2.56 \mu \mathrm{g} / \mathrm{mL})$ and IC $_{50}(0.87-2.56 \mu \mathrm{g} / \mathrm{mL})$ of AgNPs corroborate their well-known antimicrobial nature. ${ }^{25,26}$ However, the activity is not profound as that of Au-AgNPs, and still higher concentration of AgNPs is required for complete mycobacterial inhibition. AuNPs exhibited least activity where both $\mathrm{MIC}$ and $\mathrm{IC}_{50}$ was $>2.56 \mu \mathrm{g} / \mathrm{mL}$. In comparison to our earlier study with chemical and bacterial AgNPs having MIC in the range of $1.31-2.56 \mu \mathrm{g} / \mathrm{mL}$, these phytogenic $\mathrm{Au}-\mathrm{AgNPs}$ showed much better mycobactericidal activity. ${ }^{8}$ Moreover, there are no reports on bimetallic nanoparticles, although biogenic AgNPs have been demonstrated to inhibit mycobacteria. AgNPs from fungi Rhizopus stolonifer were reported to have MIC of $12.5 \mu \mathrm{g} / \mathrm{mL}$ against M. tuberculosis, ${ }^{23}$ 
Table 2 Antitubercular activity of metal nanoparticles by in vitro and ex vivo assay

\begin{tabular}{|c|c|c|c|c|c|c|c|c|c|c|c|c|}
\hline \multirow{4}{*}{$\begin{array}{l}\text { Nanoparticle } \\
\text { sample } \\
\text { designation }\end{array}$} & \multicolumn{8}{|c|}{ In vitro activity } & \multirow{2}{*}{\multicolumn{4}{|c|}{$\frac{\text { Ex vivo activity }}{\text { M. tuberculosis }}$}} \\
\hline & \multicolumn{4}{|c|}{ Mycobacterium bovis BCG } & \multicolumn{4}{|c|}{ M. tuberculosis } & & & & \\
\hline & \multicolumn{2}{|c|}{ Dormant } & \multicolumn{2}{|l|}{ Active } & \multicolumn{2}{|c|}{ Dormant } & \multicolumn{2}{|l|}{ Active } & \multicolumn{2}{|c|}{ Dormant } & \multicolumn{2}{|l|}{ Active } \\
\hline & $I_{50}$ & MIC & $I_{50}$ & MIC & $I_{50}$ & MIC & $I_{50}$ & MIC & $1 C_{50}$ & MIC & $I_{50}$ & MIC \\
\hline SI & 2.05 & $>2.56$ & 1.89 & $>2.56$ & 2.23 & $>2.56$ & 2.09 & $>2.56$ & 2.42 & $>2.56$ & 1.23 & $>2.56$ \\
\hline S2 & $>2.56$ & $>2.56$ & 1.06 & $>2.56$ & $>2.56$ & $>2.56$ & 1.31 & $>2.56$ & $>2.56$ & $>2.56$ & 1.29 & $>2.56$ \\
\hline S3 & 1.58 & $>2.56$ & 0.91 & $>2.56$ & 1.45 & $>2.56$ & 0.87 & $>2.56$ & 1.82 & $>2.56$ & 0.98 & $>2.56$ \\
\hline GI, G2, G3 & $>2.56$ & $>2.56$ & $>2.56$ & $>2.56$ & $>2.56$ & $>2.56$ & $>2.56$ & $>2.56$ & $>2.56$ & $>2.56$ & $>2.56$ & $>2.56$ \\
\hline $\mathrm{BI}$ & 0.06 & 0.45 & 0.03 & 0.42 & 0.14 & 2.26 & 0.12 & 1.56 & 0.08 & 1.22 & 0.03 & 1.17 \\
\hline B2 & 0.10 & 0.64 & 0.05 & 0.38 & 0.11 & 2.53 & 0.11 & 1.96 & 0.03 & 2.16 & 0.08 & 1.46 \\
\hline B3 & ND & 0.32 & ND & 0.42 & 0.07 & 1.05 & 0.06 & 0.93 & 0.03 & 0.56 & 0.05 & 0.63 \\
\hline Rifampicin & 0.0083 & 0.023 & 0.002 & 0.014 & 0.0014 & 0.043 & 0.0018 & 0.048 & 0.0018 & 0.048 & 0.0021 & 0.051 \\
\hline
\end{tabular}

Notes: The values are in $\mu \mathrm{g} / \mathrm{mL}$. The lowest concentration of nanoparticle inhibiting $\geq 90 \%$ and $50 \%$ with respect to the growth control without nanoparticles were taken as the MIC and IC ${ }_{50}$, respectively. The experiments were repeated thrice. SI, S2, and S3, silver nanoparticles; GI, G2, and G3, gold nanoparticles; BI, B2, and B3, gold-silver bimetallic nanoparticles.

Abbreviations: $\mathrm{IC}_{50}$, half maximal inhibitory concentration; MIC, minimum inhibitory concentration; ND, not determined.

and those synthesized using Cucumis sativus plant extract exhibited MIC ranging from 7.8 to $15.6 \mu \mathrm{g} / \mathrm{mL} .{ }^{31}$ MIC of AgNPs from P. guajava against mycobacteria has not been reported; however, inhibitory zone of $7.23 \pm 0.12 \mathrm{~mm}$ was seen at AgNP concentration of $100 \mu \mathrm{L} /$ disc. $^{21}$ In a recent study, leaf extract of 14 medicinal plants showed MIC in the range of $0.08-2.5 \mathrm{mg} / \mathrm{mL}$ against $M$. smegmatis, M. fortuitum, M. aurum, and M. tuberculosis. ${ }^{32}$

The pattern was similar in ex vivo THP-1 infection model assay with Au-AgNPs having highest efficiency to inhibit M. tuberculosis (Table 2). Morphology- and composition-dependent activity may be the plausible reason for this. ${ }^{9,28,29}$ MIC of dormant stage mycobacteria was observed to be greater than its active stage. The antimicrobial activity of an agent can be classified as significant if MIC $<100 \mu \mathrm{g} / \mathrm{mL}$, moderate if $100<$ MIC $<625 \mu \mathrm{g} / \mathrm{mL}$, and weak if MIC $>625 \mu \mathrm{g} / \mathrm{mL} .{ }^{33}$ In view of this, the overall antitubercular activity exhibited by these phytogenic nanoparticles is significant, although they possess lower potencies as compared to that of standard drug, rifampicin. Further experiments were carried out with the most effective $\mathrm{Au}-\mathrm{AgNPs}$ (B1, B2, and B3).

\section{Internalization of nanoparticles in macrophages}

Since M. tuberculosis is an intracellular pathogen, which normally resides within the intracellular compartment of macrophages, it is necessary to demonstrate that nanoparticles can enter the macrophages to exert antimycobacterial activity. Figure 2 shows the microscopic images confirming the time-dependent internalization of $\mathrm{Au}-\mathrm{AgNPs}$ in macrophages after 24 and 48 hours. Nanoparticles have been visualized through excitation at $650 \mathrm{~nm}$, without staining or tagging, due to the surface plasmon resonance effect present in noble metals. A similar technique was employed by Cronholm et $\mathrm{al}^{34}$ for the visualization of Ag-nano and CuO-nano inside A549 cells. The results indicated the significant potential of these phytogenic nanoparticles to kill TB bacteria in vivo, which needs further investigation.

\section{Cytotoxicity of Au-AgNPs toward cell lines}

Green synthesis of nanoparticles by plants is generally considered to be clean, safe, and nontoxic. Therefore, $\mathrm{Au}-\mathrm{AgNPs}$ were tested against human cell lines for their antiproliferative activity. Figure 3 represents the percentage cytotoxicity obtained against cell lines of different origin at $30 \mu \mathrm{g} / \mathrm{mL}$ concentration of Au-AgNPs through MTT assay. The concentration tested was almost ten times higher than the observed MIC for mycobacteria. Up to $45 \%$ inhibition was observed at such a high concentration of nanoparticles after 48 hours of treatment, suggesting the biocompatible nature of plant-mediated $\mathrm{Au}-\mathrm{AgNPs}$. $\mathrm{B} 2$ and $\mathrm{B} 3$ showed equivalent cytotoxicity $(16 \%-34 \%)$ against THP-1, A549, and PANC-1 cell lines, while B1 exhibited comparatively higher cytotoxicity $(20 \%-45 \%)$. Although cytotoxicity of AgNPs has been observed against human cell lines, ${ }^{35}$ it might be the gold component in Au-AgNPs that makes them biocompatible in this study. Moreover, plant-associated organic compounds involved in synthesis of $\mathrm{Au}-\mathrm{AgNPs}$ may also render them nontoxic to the cell lines.

\section{Specificity of Au-AgNPs}

To check the specificity of Au-AgNPs for mycobacteria, these nanoparticles were tested against Gram-positive 

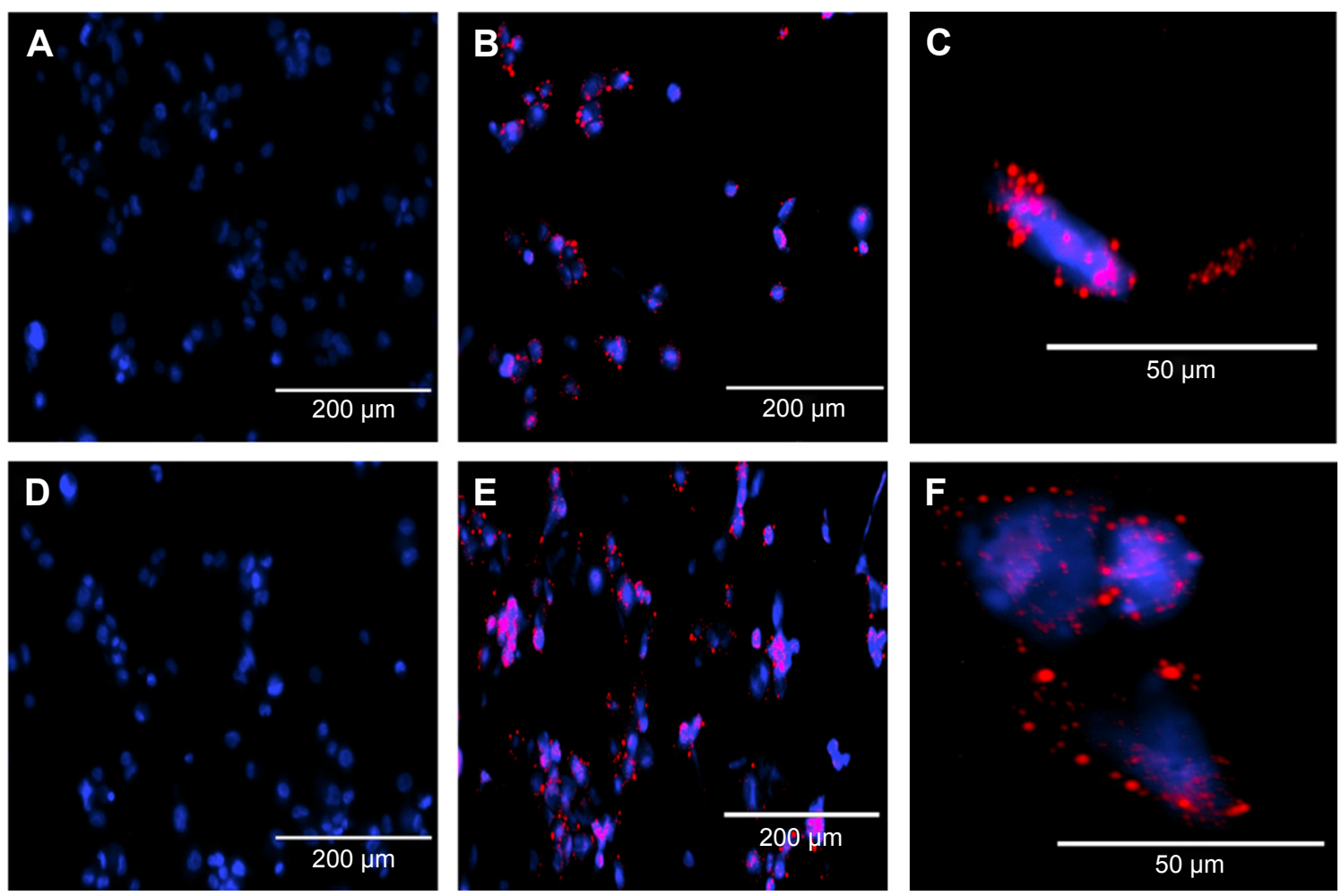

Figure 2 Internalization of B3 gold-silver bimetallic nanoparticles inside THP-I cells.

Notes: Upper panel shows image of (A) control THP-I cells $(20 \times),(B)$ THP-I cells with nanoparticles (20x), and (C) THP-I cells with nanoparticles (60X) after 24 hours treatment. Lower panel shows image of (D) control THP-I cells $(20 \times)$, (E) THP-I cells with nanoparticles (20x), and (F) THP-I cells with nanoparticles $(60 \times)$ after 48 hours treatment. Blue color corresponds to nucleus and red color denotes nanoparticles. Scale bar represents 200 and $50 \mu \mathrm{m}$ for $20 \times$ and $60 \times$ magnification, respectively. Abbreviation: THP-I, acute monocytic leukemia cell line.

and -negative bacteria to determine $\mathrm{MIC}$ and $\mathrm{IC}_{50}$ (Table 3). Gram-positive bacteria, S. aureus and S. mutans, showed higher resistance, with MIC ranging from 62 to $99 \mu \mathrm{g} / \mathrm{mL}$ for B1, B2, and B3. MIC of Gram-negative bacteria was in the

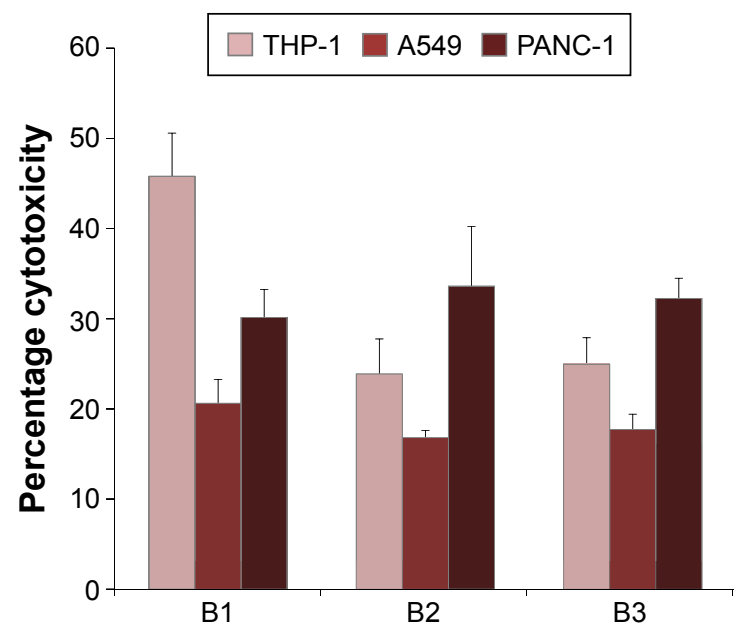

Figure 3 Percentage cytotoxicity of gold-silver bimetallic nanoparticles at $30 \mu \mathrm{g} / \mathrm{mL}$ against human cell lines.

Note: BI, B2, and B3, gold-silver bimetallic nanoparticles.

Abbreviations: THP-I, acute monocytic leukemia cell line; A549, lung adenocarcinoma cell line; PANC-I, pancreas adenocarcinoma cell line. range of $30-86 \mu \mathrm{g} / \mathrm{mL}$. This difference in activity of nanoparticles against bacteria is due to the difference in their cell wall acting as a barrier against penetration of nanoparticles. ${ }^{26,30}$ It was observed that MIC values of these Au-AgNPs are up to 39-fold higher against bacteria than that of mycobacteria. In our previous study, MIC of chemical and bacterial AgNPs was reported to be 33-fold higher than that of mycobacteria. ${ }^{8}$ This indicates that $\mathrm{Au}-\mathrm{AgNPs}$, synthesized from plants, have greater specificity toward mycobacteria.

\section{Selectivity index}

Selectivity index describes the selectivity of Au-AgNPs toward human cell line against $M$. tuberculosis (Table 4). It reflects the amount of agent/drug that is effective against mycobacteria without harming the host cells. $\mathrm{LC}_{50}$ of these nanoparticles against the tested cell lines was $>100 \mu \mathrm{g} / \mathrm{mL}$, except B1 and B3 where $\mathrm{LC}_{50}$ against THP-1 was 90.61 and 99.43, respectively. Among Au-AgNPs, B3 showed the highest selectivity index (94-108) in dormant and active stage. Selectivity index of B1 and B2 was in the range of 39-64. Previously, we obtained the selectivity index of chemical and bacterial AgNPs of up to $23 .{ }^{8}$ In a similar study, 
Table 3 Antibacterial activity of bimetallic nanoparticles against Gram-positive and -negative bacteria

\begin{tabular}{|c|c|c|c|c|c|c|c|c|}
\hline \multirow[t]{2}{*}{ Samples } & \multicolumn{2}{|c|}{$\begin{array}{l}\text { Staphylococcus } \\
\text { aureus }\end{array}$} & \multicolumn{2}{|c|}{$\begin{array}{l}\text { Streptococcus } \\
\text { mutans }\end{array}$} & \multicolumn{2}{|c|}{ Escherichia coli } & \multicolumn{2}{|c|}{$\begin{array}{l}\text { Acinetobacter } \\
\text { baumannii }\end{array}$} \\
\hline & $I_{50}$ & MIC & $I_{50}$ & MIC & $I C_{50}$ & MIC & $I C_{50}$ & MIC \\
\hline $\mathrm{BI}$ & 27.94 & 67.87 & 25.15 & 62.61 & 13.56 & 49.98 & 16.89 & 49.24 \\
\hline B2 & 34.29 & 72.39 & 26.98 & 68.23 & 12.89 & 30.34 & 20.39 & 44.12 \\
\hline B3 & 54.12 & 98.14 & 48.67 & 95.91 & 23.67 & 55.87 & 43.18 & 85.23 \\
\hline Ampicillin & 65.91 & $>100$ & 26.03 & 62.24 & 1.03 & 2.89 & $>100$ & $>100$ \\
\hline Rifampicin & $>100$ & $>100$ & $>100$ & $>100$ & 23.81 & 86.23 & 87.12 & $>100$ \\
\hline
\end{tabular}

Notes: The values are in $\mu \mathrm{g} / \mathrm{mL}$. The lowest concentrations of nanoparticle inhibiting $\geq 90 \%$ and $50 \%$ with respect to the growth control without nanoparticles were taken as the MIC and $\mathrm{IC}_{50}$, respectively. The experiments were repeated thrice. BI, B2, and B3, gold-silver bimetallic nanoparticles.

Abbreviations: $\mathrm{IC}_{50}$, half maximal inhibitory concentration; MIC, minimum inhibitory concentration.

selectivity index of leaf extract of 14 medicinal plants was reported to be in the range of $0.06-3.3,{ }^{32}$ which is far too low compared to that of phytogenic Au-AgNPs employed in this study.

Despite higher selectivity index, conventional TB drugs, such as rifampicin, are losing their functional value due to the development of resistance among mycobacteria and requirement of high dose for treatment, which can cause side effects in TB patients. ${ }^{4}$ Also, unlike antibiotics, nanoparticles do not act on microorganism in a single specific way. Multiple mechanisms, such as morphology disruption, DNA cleavage, inhibition of DNA replication, and enzyme inactivation, have been proposed to elucidate the killing action of nanoparticles, ${ }^{30}$ which makes the act of coping, adapting, and survival of microorganisms difficult in the presence of nanoparticles. Moreover, the antimycobacterial activity of an agent is considered to be specific when selectivity index $>10 .{ }^{36}$ In our report, $\mathrm{Au}-\mathrm{AgNPs}$ exhibited high selectivity index, indicating their potential as antitubercular agent, and these should be investigated further.

\section{Conclusion}

This is the first study to report the antitubercular activity of phytogenic AuNPs, AgNPs, and Au-AgNPs. Au-AgNPs

Table 4 Selectivity index of bimetallic nanoparticles on human cell lines against Mycobacterium tuberculosis

\begin{tabular}{llllllll}
\hline \multirow{2}{*}{ Samples } & \multicolumn{3}{l}{ Dormant state } & & \multicolumn{3}{l}{ Active state } \\
\cline { 2 - 3 } \cline { 6 - 7 } & THP-I & A549 & PANC-I & & THP-I & A549 & PANC-I \\
\hline BI & 40.09 & 44.25 & 44.25 & & 58.08 & 64.10 & 64.10 \\
B2 & 39.53 & 39.53 & 39.53 & & 51.02 & 51.02 & 51.02 \\
B3 & 94.69 & 95.24 & 95.24 & & 106.91 & 107.53 & 107.53 \\
Rifampicin & 666.67 & 666.67 & 666.67 & & $1,041.67$ & $1,041.67$ & I,04I.67 \\
\hline
\end{tabular}

Notes: Selectivity index was calculated by dividing $\mathrm{LC}_{50}$ for cell lines by the MIC for in vitro activity against active/dormant $M$. tuberculosis. BI, B2, and B3, gold-silver bimetallic nanoparticles.

Abbreviations: THP-I, acute monocytic leukemia cell line; A549, lung adeno-

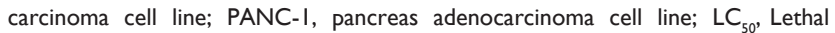
concentration, 50\%; MIC, minimum inhibitory concentration. exhibited profound efficiency to inhibit mycobacteria in dormant and active stage. Among these, $\mathrm{Au}-\mathrm{AgNPs}$ synthesized from S. cumini showed greater specificity and selectivity toward mycobacteria. The results obtained with $\mathrm{Au}-\mathrm{AgNPs}$ are much more promising compared to our earlier study with AgNPs obtained from bacterial and chemical reduction, with almost four times increase in selectivity. Moreover, satisfactory biocompatibility against human cancer cell lines makes them good candidates for further investigation in the search for new active therapeutic compounds. Although rifampicin has very high selectivity, the importance of this study lies in the fact that microorganisms are rapidly acquiring resistance against conventional drugs and that alternative strategies are urgently needed. Studies on effects of combination of $\mathrm{Au}-\mathrm{AgNPs}$ and TB drugs against mycobacteria are under investigation. Moreover, experimental studies are needed to gauge the in vivo significance of these nanoparticles, either individually or in synergy with other antibiotics. Mechanism of antimycobacterial activity of nanoparticles also warrants further investigation.

\section{Acknowledgments}

RS and SW acknowledge the University Grants Commission (UGC), New Delhi, for research fellowship. US thanks UGC for UGC-DS Kothari postdoctoral fellowship. The authors also thank Dr DS Gond, Department of Microbiology, Savitribai Phule Pune University (SPPU), Pune, and Ms Gayatri Salunke, Institute of Bioinformatics and Biotechnology, SPPU, for providing phytogenic nanoparticles for the study.

\section{Disclosure}

The authors report no conflicts of interest in this work.

\section{References}

1. Lin PL, Flynn JL. Understanding latent tuberculosis: a moving target. J Immunol. 2010;185(1):15-22.

2. Jawahar MS. Current trends in chemotherapy of tuberculosis. Indian J Med Res. 2004;120(4):398-417. 
3. World Health Organization. Global Tuberculosis Report 2015; 2016. Available from: http://www.who.int/tb/publications/global_report/en/. Accessed February 26, 2016.

4. Gandhi NR, Nunn P, Dheda K, et al. Multidrug-resistant and extensively drug-resistant tuberculosis: a threat to global control of tuberculosis. Lancet. 2010;375(9728):1830-1843.

5. Ganihigama DU, Sureram S, Sangher S, et al. Antimycobacterial activity of natural products and synthetic agents: pyrrolodiquinolines and vermelhotin as anti-tubercular leads against clinical multidrug resistant isolates of Mycobacterium tuberculosis. Eur J Med Chem. 2015;89: $1-12$.

6. Ramprasad J, Nayak N, Dalimba U. Design of new phenothiazinethiadiazole hybrids via molecular hybridization approach for the development of potent antitubercular agents. Eur J Med Chem. 2015; 106:75-84.

7. Mhiri C, Boudriga S, Askri M, et al. Design of novel dispirooxindolopyrrolidine and dispirooxindolopyrrolothiazole derivatives as potential antitubercular agents. Bioorg Med Chem Lett. 2015;25(19):4308-4313.

8. Singh R, Nawale LU, Arkile M, et al. Chemical and biological metal nanoparticles as antimycobacterial agents: a comparative study. Int J Antimicrob Agents. 2015;46(2):183-188.

9. Salunke GR, Ghosh S, Santoshkumar RJ, et al. Rapid efficient synthesis and characterization of silver, gold and bimetallic nanoparticles from the medicinal plant Plumbago zeylanica and their application in biofilm control. Int J Nanomedicine. 2014;9:2635-2653.

10. Ghosh S, Jagtap S, More P, et al. Dioscorea bulbifera mediated synthesis of novel $\mathrm{Au}_{\text {core }} \mathrm{Ag}_{\text {shell }}$ nanoparticles with potent antibiofilm and antileishmanial activity. $J$ Nanomater. 2015;2015:562938.

11. Iravani S. Green synthesis of metal nanoparticles using plants. Green Chem. 2011;13:2638-2650.

12. Ayyanar M, Subash-Babu P. Syzygium cumini (L.) skeels: a review of its phytochemical constituents and traditional uses. Asian Pac J Trop Biomed. 2012;2(3):240-246.

13. Banerjee D, Maji AK, Mahapatra S, Banerji P. Barleria prionitis Linn.: a review of its traditional uses, photochemistry, pharmacology and toxicity. Res J Phtochem. 2012;6:31-41.

14. de Paiva SR, Figueiredo M, Aragão TV, Kaplan MA. Antimicrobial activity in vitro of plumbagin isolated from Plumbago species. Mem Inst Oswaldo Cruz. 2003;98(7):959-961.

15. Deshpande LM, Chopade BA. Plasmid mediated silver resistance in Acinetobacter baumannii. Biometals. 1994;7(1):49-56.

16. Ghosh S, Patil S, Ahire M, et al. Synthesis of silver nanoparticles using Dioscorea bulbifera tuber extract and evaluation of its synergistic potential in combination with antimicrobial agents. Int J Nanomedicine. 2012;7:483-496.

17. Khan A, Sarkar D. A simple whole cell based high throughput screening protocol using Mycobacterium bovis BCG for inhibitors against dormant and active tubercle bacilli. J Microbiol Methods. 2008;73(1): $62-68$.

18. Singh U, Akhtar S, Mishra A, Sarkar D. A novel screening method based on menadione mediated rapid reduction of tetrazolium salt for testing of anti-mycobacterial agents. J Microbiol Methods. 2011;84(2): 202-207.

19. Ciapetti G, Cenni E, Pratelli L, Pizzoferrato A. In vitro evaluation of cell/biomaterial interaction by MTT assay. Biomaterials. 1993;14(5): 359-364.
20. Luo X, Pires D, Ainsa JA, et al. Zanthoxylum capense constituents with anti-mycobacterial activity against Mycobacterium tuberculosis in vitro and ex vivo within human macrophages. J Ethnopharmacol. 2013; 146(1):417-422.

21. Kote JR, Mulani RM, Kadam AS, Solankar BM. Anti-mycobacterial activity of nanoparticles from Psidium guajava L. J Microbiol Biotechnol Res. 2014;4(5):14-17.

22. Naik SK, Mohanty S, Padhi A, Pati R, Sonawane A. Evaluation of antibacterial and cytotoxic activity of Artemisia nilagirica and Murraya koenigii leaf extracts against mycobacteria and macrophages. $B M C$ Complement Altern Med. 2014;14:87-96.

23. Banu A, Rathod V. Biosynthesis of monodispersed silver nanoparticles and their activity against Mycobacterium tuberculosis. J Nanomed Biotherapeut Discov. 2013;3:110-114.

24. Mohanty S, Jena P, Mehta R, et al. Cationic antimicrobial peptides and biogenic silver nanoparticles kill mycobacteria without eliciting DNA damage and cytotoxicity in mouse macrophages. Antimicrob Agents Chemother. 2013;57(8):3688-3698.

25. Gaidhani S, Singh R, Singh D, et al. Biofilm disruption activity of silver nanoparticles synthesized by Acinetobacter calcoaceticus PUCM 1005 Mater Lett. 2013;108:324-327.

26. Singh R, Wagh P, Wadhwani S, et al. Synthesis, optimization, and characterization of silver nanoparticles from Acinetobacter calcoaceticus and their enhanced antibacterial activity when combined with antibiotics. Int J Nanomedicine. 2013;8:4277-4290.

27. Cui Y, Zhao Y, Tian Y, Zhang W, Lü X, Jiang X. The molecular mechanism of action of bactericidal gold nanoparticles on Escherichia coli. Biomaterials. 2012;33(7):2327-2333.

28. Pal S, Tak YK, Song JM. Does the antibacterial activity of silver nanoparticles depend on the shape of the nanoparticle? A study of the Gramnegative bacterium Escherichia coli. Appl Environ Microbiol. 2007; 73(6): 1712-1720.

29. Adams CP, Walker KA, Obare SO, Docherty KM. Size-dependent antimicrobial effects of novel palladium nanoparticles. Plos One. 2014; 9(1):e85981.

30. Singh R, Shedbalkar UU, Wadhwani SA, Chopade BA. Bacteriagenic silver nanoparticles: synthesis, mechanism, and applications. Appl Microbiol Biotechnol. 2015;99(11):4579-4593.

31. Agarwal P, Mehta A, Kachhwaha S, Kothari SL. Green synthesis of silver nanoparticles and their activity against Mycobacterium tuberculosis. Adv Sci Eng Med. 2013;5(7):709-714.

32. Dzoyem JP, Aro AO, McGaw LJ, Eloff JN. Antimycobacterial activity against different pathogens and selectivity index of fourteen medicinal plants used in southern Africa to treat tuberculosis and respiratory ailments. S Afr J Bot. 2016;102:70-74.

33. Kuete V. Potential of Cameroonian plants and derived products against microbial infections: a review. Planta Med. 2010;76(14):1479-1491.

34. Cronholm P, Karlsson HL, Hedberg J, et al. Intracellular uptake and toxicity of $\mathrm{Ag}$ and Cuo nanoparticles: a comparison between nanoparticles and their corresponding metal ions. Small. 2013;9:970-982.

35. de Lima R, Seabra AB, Duran N. Silver nanoparticles: a brief review of cytotoxicity and genotoxicity of chemically and biogenically synthesized nanoparticles. J Appl Toxicol. 2012;32(11):867-879.

36. Hartkoorn RC, Chandler B, Owen A, et al. Differential drug susceptibility of intracellular and extracellular tuberculosis and impact of P-glycoprotein. Tuberculosis. 2007;87(3):248-255.
International Journal of Nanomedicine

\section{Publish your work in this journal}

The International Journal of Nanomedicine is an international, peerreviewed journal focusing on the application of nanotechnology in diagnostics, therapeutics, and drug delivery systems throughou the biomedical field. This journal is indexed on PubMed Central,

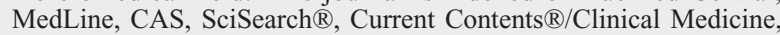

\section{Dovepress}

Journal Citation Reports/Science Edition, EMBase, Scopus and the Elsevier Bibliographic databases. The manuscript management system is completely online and includes a very quick and fair peer-review system, which is all easy to use. Visit http://www.dovepress.com/ testimonials.php to read real quotes from published authors. 